\title{
The Controversial Status of International and Comparative Law in the United States
}

\section{Citation}

Martha Minow, The Controversial Status of International and Comparative Law in the United States, 52 Harv. Int'l L.J. Online 1 (2010), http://www.harvardilj.org/2010/08/online_52_minow/.

\section{Permanent link}

http://nrs.harvard.edu/urn-3:HUL.InstRepos:10511098

\section{Terms of Use}

This article was downloaded from Harvard University's DASH repository, and is made available under the terms and conditions applicable to Open Access Policy Articles, as set forth at http:// nrs.harvard.edu/urn-3:HUL.InstRepos:dash.current.terms-of-use\#OAP

\section{Share Your Story}

The Harvard community has made this article openly available.

Please share how this access benefits you. Submit a story.

\section{Accessibility}




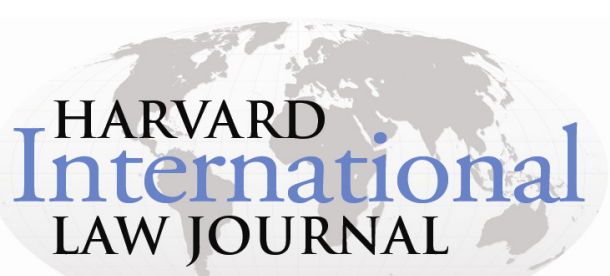

HARVARD ILJ ONLINE

VOLUME 52 - AUGUST 27, 2010

\section{The Controversial Status of International and Comparative Law in the United States}

Martha Minow ${ }^{\dagger}$

\section{INTRODUCTION}

In recent years, I have watched the swirling debate over whether the United States courts should consult international or comparative law. As a law professor, the debate has puzzled me, for international and comparative legal materials have always appeared in the sources consulted by American lawyers and judges. So this article is really a search for the roots of the contemporary controversy. Why is there a controversy? And what can we learn from it?

I will suggest three conjectures to explain the fact of the contemporary debate over the proper role of international law within the United States:

(1) a basic concern emphasizes that we risk being taken over, or losing what we are by engaging with others;

(2) a second worry stresses that the United States is exceptional and thus faces politically motivated attacks as the last superpower;

(3) a third very specific trepidation arises from the unusual nature of "customary international law."

My hope is that by locating the sources of the controversy over the place of international law within the United States, we can dismiss artificial issues and focus on genuine and significant developments-broader changes that offer a window onto the prospects for more effective human governance. The debate diverts attention from

\footnotetext{
* This article is based on a speech given at the Chicago Council on Global Affairs on May 10, 2010, and the closing discussion draws from the author's recently published book, IN BROWN'S WAKE: LEGACIES OF AMERICA'S EDUCATIONAL LANDMARK (2010).

${ }^{\dagger}$ Dean and Jeremiah Smith, Jr. Professor, Harvard Law School. Thanks to Jackie Martínez for research assistance.
} 
developments that might be instructive to us not just in what US courts do but, more importantly, in how we design legislation and legal institutions and how we understand our place in the world.

First, we need to see the puzzle: what is the contemporary debate and how does it relate to judicial practice in the United States?

\section{THE CONTEMPORARY DeBATE AND THE PUZZLE}

Here is the puzzle: no one disagrees that United States judges have long consulted and referred to materials from other countries as well as international sources; yet for the past nine or so years, citing foreign and international sources has provoked intense controversy.

The evidence of the longstanding practice is undisputed and well-forecast by one of the Federalist Papers, which asserted, "attention to the judgment of other nations is important to every government" as a matter of foreign policy and also as a check on "strong passion or momentary interest" within the nation. ${ }^{1}$ The U.S. Constitution itself accords to Congress the authority to "define and punish Piracies and Felonies committed on the high Seas, and Offences against the Law of Nations."2 Citations to foreign law appear in Supreme Court opinions from 1823 (dealing with Native Americans), ${ }^{3} 1832$ (defining the status of Indian tribes) ${ }^{4}, 1877$ (concerning personal jurisdiction), ${ }^{5}$ and 1879 (rejecting polygamy) ${ }^{6}$. In 1900, the Supreme Court ruled that "international law is part of our law." J Justices on the Supreme Court have consulted and referred to the laws of other nations in addressing slavery, ${ }^{8}$ mandatory vaccinations, ${ }^{9}$ regulation of wheat markets, ${ }^{10}$ emergency governmental powers, ${ }^{11}$ the meaning of cruel and unusual punishment, ${ }^{12}$ rights upon arrest, ${ }^{13}$ abortion, ${ }^{14}$

\footnotetext{
${ }^{1}$ The Federalist No. 63 (James Madison). See also 4 William Blackstone, COMMENTARIES *67 (stating that the common law adopts the law of nations).

2 U.S. CONST. art. I, $\int 8$.

${ }^{3}$ Johnson v. M'Intosh, 21 U.S. (8 Wheat.) 543, 574-85, 592-96 (1823).

4 Worcester v. Georgia, 31 U.S. 515, 551-552 (1832).

5 Pennoyer v. Neff, 95 U.S. 714, 729-30 (1877).

${ }^{6}$ Reynolds v. United States, 98 U.S. 145, 164-65 (1879).

7 The Paquete Habana, 175 U.S. 677, 700 (1900). See also Murray v. Schooner Charming Betsy, 6 U.S. 64, 80 (1804) (Chief Justice Marshall agreed with the complainant that "an act of Congress ought never to be construed to violate the law of nations if any other possible construction remains").

${ }^{8}$ Dred Scott v. Sanford, 60 U.S. 393, 407-08, 451 (1857).

${ }^{9}$ Jacobson v. Massachusetts, 197 U.S. 11, 31-32 (1905).

10 Wickard v. Filburn, 317 U.S. 111, 125-26 (1942).

11 Youngstown Sheet \& Tube Co. v. Sawyer, 343 U.S. 579, 651-52 (1952) (Jackson, J., concurring).

12 Trop v. Dulles, 356 U.S. 86, 103 (1958).

${ }^{13}$ Miranda v. Arizona, 384 U.S. 436, 486-87 (1966)

${ }^{14}$ Roe v. Wade, 410 U.S. 113, 136-38 (1973).
} 
sodomy, ${ }^{15}$ and end-of-life treatment. ${ }^{16}$ Judge Frank Easterbrook reviewed the use of foreign sources by U.S. courts and concluded that the practice "has been stable for a long time; any suggestion that the practice has skyrocketed recently is unfounded."17

Others have noted that consideration by U.S. judges of decisions or practices from other countries and international bodies is fundamentally no different than references to law review articles, materials from state courts, or Shakespeare, in that each is "filtered through the analytical machinery of a U.S. court" and treated not as binding but merely as potentially instructive. ${ }^{18}$

Whether identified as foreign law, international law, or comparative law, what if any role should legal materials originating from outside domestic U.S. practice play inside the legal system of this country? It is worth noting at the outset that the discussion tends to merge these categories-international and comparative lawalthough all that they share is "not U.S. in origin." Let me flag for later emphasis: where international law does have endorsement by the United States, then it too is U.S. law. Although this point gets obscured, let us acknowledge that the debate sweeps in consultation of constitutions, statutes, and judicial decisions from other countries, as well as international treaties we have not signed, international treaties we have signed, and other sources of international law.

Current members of the U.S. Supreme Court advance the most visible edge of the contemporary debate over this issue. When Justices of the United States Supreme Court give public speeches, they seldom replay fights internal to the Court on the results of particular cases, but more commonly explore disagreements about methods of interpretation and the roles of judges and the judiciary.

During his Senate confirmation hearing, Chief Justice John Roberts objected to reference to international law by U.S. courts because international law "doesn't limit [judges'] discretion the way relying on domestic precedent does," and consulting how other countries treat particular legal questions pending in the United States is like "looking out over a crowd and picking out your friends." 19 During his own confirmation hearing, Justice Samuel Alito emphasized that "The Framers [of the United States Constitution] did not want Americans to have the rights of people in France or the rights of people in Russia, or any of the other countries on the

\footnotetext{
${ }^{15}$ Lawrence v. Texas, 539 U.S. 558, 573 (2003).

16 Washington v. Glucksberg, 521 U.S. 702,718 n.16 (1997). See generally Steven G. Calebresi \& Stephanie Dotson Zimdahl, The Supreme Court and Foreign Sources of Law: Two Hundred Years of Practice and the Juvenile Death Penalty Decision, 47 WM. \& MARY L. REV. 743 (2005).

${ }^{17}$ Frank H. Easterbrook, Foreign Sources and the American Constitution, 30 HARV. J.L. \& PUB. POL'Y 223, 223 (2006).

${ }^{18}$ Chimène I. Keitner, International and Foreign Law Sources: Siren Song for U.S. Judges?, 3 AdVANCE: J. ACS Issue GROUPS 215 (2009). See also Easterbrook, supra note 17 (cautioning against citation of any sources to support judicially-announced changes in the Constitution or national law).

${ }^{19}$ Confirmation Hearing on the Nomination of John G. Roberts, Jr. to be Chief Justice of the United States: Hearing Before the S. Comm. on the Judiciary, 109th Cong. 201 (2005) (statement of Judge John G. Roberts, Jr.).
} 
continent of Europe at the time. They wanted them to have the rights of Americans, and ... I don't think it's appropriate to look to foreign law." 20

Justice Thomas wrote concurring in a denial of certiorari, "While Congress, as a legislature, may wish to consider the actions of other nations on any issue it likes, this Court's Eighth Amendment jurisprudence should not impose foreign moods, fads, or fashions on Americans." 21 In a 2004 opinion, Justice Antonin Scalia chided fellow Justices for inviting implying that the "law of nations," which he described as "redefined to mean the consensus of states on any subject," could ever bind citizens in our territory because, he wrote, this idea is "a $20^{\text {th }}$-century invention of internationalist law professors and human rights advocates" 22 and is inconsistent with both the understanding of our Constitution's framers and democracy. Scalia viewed international human rights law to be "a fantasy." 23 In another recent opinion, Justice Scalia objected to the citation of the laws of other nations as irrelevant and inconsistent, and also noted that that “'[a]cknowledgment' of foreign approval has no place in the legal opinion of this Court unless it is part of the basis for the Court's judgment-which is surely what it parades as today." 24

Some members of Congress decided to join the fray and even suggested censure or impeachment of a judge who cites non-U.S. sources. ${ }^{25}$ Members of Congress have repeatedly introduced resolutions such as this one: "judicial interpretations regarding the meaning of the Constitution of the United States should not be based in whole or in part on judgments, laws, or pronouncements of foreign institutions unless such foreign judgments, laws, or pronouncements inform an understanding of the original meaning of the Constitution of the United States." 26 Senator John Cornyn introduced this resolution into the Senate by warning that a trend of citing foreign decisions, if real, would mean that "the American people may be losing control over the meaning of our laws and of our Constitution. If this trend continues, foreign governments may even begin to dictate what our laws and our Constitution mean, and what our policies in America should be." 27 During the Senate confirmation hearings for Justice Elena Kagan, Senator Jon Kyl said he was troubled by the suggestion "you can turn to foreign law to get good ideas." 28 Former Attorney General Alberto Gonzales

${ }^{20}$ Confirmation Hearing on the Nomination of Samuel A. Alito to be an Associate Justice of the Supreme Court of the United States: Hearing Before the S. Comm. on the Judiciary, 109th Cong. 471 (2006) (statement of Judge Samuel A. Alito).

${ }^{21}$ Foster v. Florida, 537 U.S. 990, 990 n.1 (Thomas, J., concurring in the denial of certiorari).

22 Sosa v. Alvarez-Machain, 542 U.S. 692, 749-50 (2004) (Scalia, J., concurring in part and concurring in the judgment).

${ }^{23}$ Harlan Grant Cohen, Supremacy and Diplomacy: The International Law of the U.S. Supreme Court, 24 BERKELEY J. INT'L L. 273, 310 (2006).

24 Roper v. Simmons, 543 U.S. 551, 628 (2005) (Scalia, J., dissenting).

25 See Judicial Conduct Act of 2007, H.R. 2898, 110th Cong. (2007); Dana Milbank, And the

Verdict on Justice Kennedy Is: Guilty, WASH. POST, Apr. 9, 2005, at A3.

${ }^{26}$ H.R. Res. 372, 110th Cong. (2007); S. Res. 92, 109th Cong. (2005).

27151 Cong. REC. S3109 (daily ed. March 20, 2005) (statement of Sen. John Cornyn).

${ }^{28}$ Confirmation Hearing on the Nomination of Elena Kagan to be an Associate Justice of the Supreme Court

of the United States: Hearing Before the S. Comm. on the Judiciary, 111 th Cong. (June 30, 2010). 
objected that foreign legal sources should not be used in U.S. courts because their authors "are not accountable to the American people." 29 In sum, critics charge that references to non-U.S. sources by American judges can be selective, faddish, and cover for the judges' own unaccountable views, or a departure from American democracy and authority.

When it comes to keeping Congress out of their business, perhaps all the Justices could agree. Hence, Justice Scalia in a speech in 2006 declared, "As much as I think that it is improper to use foreign law to determine the meaning of the Constitution, I don't think it's any of [Congress's] business." 30

But on the place of foreign and international law within U.S. law, Justices Breyer, Ginsburg, and Kennedy have diverged from the views already described. Justice Breyer does not only refer to foreign and international legal sources, ${ }^{31}$ he also emphatically defends this practice, noting:

[W] hen I do read things, I can read what I want. If I see something written by a man or a woman who has a job like mine in another country, and who is interpreting a document somewhat like mine and who in fact has a problem in front of the court somewhat like mine, why can't I read it, see what they've done? I might learn something. ${ }^{32}$

Justice Breyer has asserted that international law importantly reflects a globalization of human rights and "near-universal desire for judicial institutions that, through guarantees of fair treatment, help to provide the security necessary for investment and, in turn, economic prosperity." 33 Foreign governmental responses, in his view, may "cast an empirical light on the consequences of different solutions to a common legal problem." 34 Justice Breyer has also commented: "I know it's not binding," when the authority comes from outside the United States, and, in his words, "so what's the problem?" 35

Justice Ruth Bader Ginsburg similarly has commented that "Judges in the United States are free to consult all manner of commentary-Restatements, Treatises, what law professors or even law students write copiously in law reviews ... why not the

${ }^{29}$ Alberto Gonzales, U.S. Att'y Gen., Remarks at George Mason University (Oct. 18, 2005) (transcript available at http://www.justice.gov/archive/ag/speeches/2005/ag_speech_051018.html).

${ }^{30}$ Scalia Criticizes Use of Foreign Law in Interpreting U.S. Constitution, Fox NEws, May 18, 2006, available at http://www.foxnews/com/story/0,2933,196114,00.html.

31 See, e.g., Knight v. Florida, 120 S.Ct. 459, 462-463 (1999) (Breyer, J., dissenting) (mem.) (citing decisions from Jamaica, India, Zimbabwe, and the European Court of Human Rights). 32 Jesse J. Holland, Justice Breyer Says Debate Over Foreign Law is Irrelevant, AssOCIATED PRESS, Apr. 2, 2010, available at http://www.law.com/jsp/scm/PrintFriendly.jsp?id=1202447364424. ${ }_{33}$ Associate Justice Stephen Breyer, Keynote Address: The Supreme Court And The New International Law, 97 AM. SOC’Y INT’L L. Proc. 265, 267 (2003).

${ }^{34}$ Id. at 266.

${ }^{35}$ Holland, supra note 32. 
analysis of a question similar to one we confront contained in an opinion of the Supreme Court of Canada, the Constitutional Court of South Africa, the German Constitutional Court, or the European Court of Human Rights?"36 More controversially, she has stated, "We are losers if we neglect what others can tell us about endeavors to eradicate bias against women, minorities, and other disadvantaged groups." 37 Indeed, she stresses that lack of engagement with foreign decisions has reduced the influence of the Supreme Court. ${ }^{38}$ Following the Senate confirmation hearings for Justice Kagan, Justice Ginsburg speech stressed, "The U.S. judicial system will be the poorer, I have urged, if we do not both share our experience with, and learn from, legal systems with values and a commitment to democracy similar to our own." 39 Citing reference to foreign opinion or law by the authors of the Declaration of Independence, the authors of the Federalist Papers, and by Supreme Court opinions, Justice Ginburg predicted that the U.S. Supreme Court will continue to accord "a 'decent Respect to the Opinions of [Human]kind' as a matter of comity and in a spirit of humility." 40

Justice Anthony Kennedy previously objected to the idea that judgments from foreign constitutional courts could contribute to the development of American constitutional law, but in recent years he has cited foreign sources in key opinions. In Lawrence v. Texas, invalidating Texas' sodomy statute, Justice Kennedy pointed to the decriminalization of sodomy by the British Parliament in 1967, the European Convention on Human rights, and a 1981 European Court of Human Rights decision. ${ }^{41}$ In Roper $v$. Simmons, explaining the Court's rejection of the death penalty applied to a crime committed by a minor, Justice Kennedy's analysis of the Eighth Amendment Cruel and Unusual Punishment Clause included consideration of "the world community" as providing "respected and significant confirmation for our own

\footnotetext{
${ }^{36}$ Ruth Bader Ginsburg, Associate Justice, Supreme Court of the United States, Speech at the Constitutional Court of South Africa: "A Decent Respect to the Opinions of [Human]kind": The Value of a Comparative Perspective in Constitutional Adjudication (Feb. 7, 2006) (transcript available at http://www.supremecourt.gov/publicinfo/speeches/viewspeeches.aspx?Filename=sp_0207b-06.html).

${ }^{37}$ Breyer, supra note 33 (quoting Ginsburg, J.).

38 Adam Liptak, Ginsburg Shares Views on Influence of Foreign Law on Her Court, and Vice Versa, N.Y. Times, Apr. 12, 2009, at A14.

${ }^{39}$ Ruth Bader Ginsburg, Associate Justice, Supreme Court of the United States, Speech at the International Academy of Comparative Law, American University: "A Decent Respect to the Opinions of [Human]kind": The Value of a Comparative Perspective in Constitutional Adjudication (July 30, 2010) (transcript available at http://www.supremecourt.gov/publicinfo/speeches/viewspeeches.aspx?Filename=sp_08-0210.html). Noting how the framers set the "high importance" of observing the "laws of nations," Justice Ginsburg reiterated Elena Kagan's position that foreign opinions "set no binding precedent for the U.S. judge. But they can add to the store of knowledge relevant to the solution of trying questions." Id.

${ }^{40} I d$.

41539 U.S. at 572-73.
} 
conclusions." 42 Justice Kennedy added, "It does not lessen fidelity to the Constitution ... to acknowledge that the express affirmation of certain fundamental rights by other nations and peoples underscores the centrality of those same rights within our own heritage of freedom." 43

Justice Sonia Sotomayor has also supported "broader consideration of foreign and international law in U.S. judicial opinions,"44 and in 2009 in a speech stated, "to the extent that we have freedom of ideas, international law and foreign law will be very important in the discussion of how to think about the unsettled issues in our legal system," 45 though she has also maintained that such sources have "very limited formal force" and she joins Justices Scalia and Thomas in warning of selection bias in the use of international legal sources. ${ }^{46}$ While on the Court, Chief Justice Rehnquist and Justice Sandra Day O'Connor at times supported judicial consultation of decisions of other constitutional courts outside the United States..$^{47}$

Yet since 2003, a serious political as well as theoretical fight over judicial reference by U.S. judges to non-U.S. sources has broken out in the opinions of Supreme Court Justices, on the lecture circuit, in law reviews, and in Congress. Intensity of feeling around these debates should not be underestimated. Justice Ginsburg reported a death threat was posted on a website in 2005 against both her and Justice O'Connor in reference to their discussions of international law in the

\footnotetext{
42543 U.S. at 578.

${ }^{43} I d$.

${ }^{44}$ Collin Levy, Op-Ed., Sotomayor and International Law, WALL. ST. J., July 14, 2009, at A13.

${ }^{45}$ Steven Groves, Questions for Justice Sotomayor on the Use of Foreign and International Law, THE HERITAGE FOUNDATION, July 6, 2009, available at

http://www.heritage.org/Research/Reports/2009/07/Questions-for-Judge-Sotomayor-onthe-Use-of-Foreign-and-International-Law at note 12 and accompanying text (quoting speech by Sotomayor, J. to the ACLU in Puerto Rico).

${ }^{46} I d$.

47 See William Rehnquist, Constitutional Courts - Comparative Remarks, in 14 GERMANY AND ITS BASIC LAW: PAST, PRESENT AND FUTURE -TuRERERMAN-AMERICAN SYMPOSIUM 411, 412 (Paul Kirchhof \& Donald P. Kommers eds., 1993) ("now that constitutional law is solidly grounded in so many countries, it is time that the United States courts begin looking to the decisions of other constitutional courts to aid in their own deliberative processes"); SANDRA DAY O'CONNOR, THE MAJESTY OF THE LAW: REFLECTIONS OF A SUPREME COURT JUSTICE 234 (2003) ("As the American model of judicial review of legislation spreads further around the globe, I think that we Supreme Court Justices will find ourselves looking more frequently to the decisions of other constitutional courts, especially other common-law courts that have struggled with the same basic constitutional questions that we have: equal protection, due process, the Rule of Law in constitutional democracies. . . All of these courts have something to teach us about the civilizing function of constitutional law."). On the bench, however, in interpreting the Eighth Amendment, Chief Justice Rehnquist wrote, "if it is evidence of a national consensus for which we are looking, then the viewpoints of other countries simply are not relevant." Atkins v. Virginia, 536 U.S. 304, 325 (Rehnquist, C.J., dissenting).
} 
context of judicial decision-making. ${ }^{48}$ Justice Ginsburg cautioned that the congressional debates seemed to "fuel the irrational fringe." 49

\section{WHY THE BIG FIGHT?}

\section{A. Fear of Being TAKen Over and Losing Control}

Senator Cornyn offered a cogent explanation of the first source of the fight over turning to foreign law: a basic concern about identity and autonomy-that we risk being taken over and losing what we are by engaging with others. This concern squarely hits the use of comparative law, the law of Germany, Canada, South Africa, Israel, or other countries, rather than consultation of international law, though that, too, could raise similar worries. There is an obvious intersection between this set of concerns and debates over judicial interpretation and constitutional construction. Justice Scalia, for example, is explicit in his advocacy of "originalism," directing judges to construe the United States Constitution to discern the meaning of its drafters. Justice Scalia connects this method to his resistance to foreign sources in noting, "the men who founded our republic did not aspire to emulate Europeans, much less the rest of the world . . . and nothing has changed." ${ }^{50}$ Justice Breyer emphasizes, in contrast, that the Declaration of Independence itself points to a "decent respect to the opinions of mankind," ${ }_{11}$ and Justice Breyer has articulated a philosophy of judicial interpretation that pursues the underlying values of fostering democracy and the wellbeing of citizens. ${ }^{52}$

For Senator Cornyn and others, U.S. judges risk losing tight adherence to strictly U.S. text and values if they consult the laws or decisions of other nations to construe terms within the U.S. Constitution. Attacks against consideration of foreign sources can reflect not only concerns about confining judges to the views held by the Constitution's framers but also disagreements over the results in cases like Lawrence $v$. Texas — striking down a statute criminalizing sodomy-and Roper $v$. Simmonsrejecting the death penalty applied to a crime committed by a minor. An author posting on the National Review website comments that this consultation of foreign and international law to assist interpretation of the U.S. Constitution could allow a judge to "reach the result he wants to reach" with no restrictions, and with the effect

\footnotetext{
48 See Bill Mears, Justice Ginsburg Details Death Threat, CNN, Mar. 15, 2006, http://www.cnn.com/2006/LAW/03/15/scotus.threat.

${ }^{49} \mathrm{Id}$.

50 Antonin Scalia, Associate Justice, Supreme Court of the United States, Remarks at the American Enterprise Institute on the Role that International and Foreign Law Should Play in American Judicial Decision-Making (Feb. 21, 2006) (transcript available from CQ Transcriptions).

${ }^{51}$ Tom Curry, A Flap over Foreign Matter at the Supreme Court, MSNBC, Mar. 11, 2004, http://www.msnbc.msn.com/id/4506232.

52 STEPHEN BREYER, ACTIVE LIBERTY (2005).
} 
of "depriving American citizens of their powers of representative government by selectively imposing on them favored policies of Europe's leftist elites." 53 As no one argues that foreign sources are in any way binding on the United States, the objection merely to consulting them is thus often simply part of the critique of the outcomes.

Yet there is another worry about the consultation of foreign sources that seems to operate at a psychological or sociological level of concern. The sheer act of looking at decisions or opinions from non-U.S. sources is the apparent problem-so why? There seems to be a fear of temptation or loss of control. If merely looking at what others are doing causes the worry, the concern seems to be about caving to peer pressure or being an outlier-some kind of contagion effect. Justice Breyer must sense this objection for he responds, "comparative use of foreign constitutional decisions will not lead us blindly to follow the foreign court," and "of course, we are interpreting our own Constitution ... and there may be relevant political and structural differences between their systems and our own." 54

This recognition of differences offers a response to the fear that our judges will be contaminated, unable to resist, or taken over if they consult constitutional materials from other countries. The assumption that looking at what others do leads to following them neglects the genuine possibility that looking at others will lead to greater conviction about remaining different or to increased clarity about the reasons for going a different way. As Professor Vicki Jackson at Georgetown University Law Center emphasizes, the process of engagement with comparative materials is as likely to help American judges clarify what is not consistent with the text and traditions of the United States as it is to be instructive in interpreting American commitments. ${ }^{55}$ For example, in viewing the treatment of hate speech in Canada and Germany, where courts have upheld and applied restrictions, analysis of the American constitutional tradition rejects the path pursued elsewhere as disconnected from our text and commitments, as well as reflective of different contexts and concerns. ${ }^{56}$ Looking at what others do may sharpen our sense of our differences rather than produce a sense of pressure to conform.

This reminds me of the critical lesson my mother taught my sisters and me. As my sister Nell explained recently:

\footnotetext{
${ }^{53}$ Ed Whelan, Obama Supreme Court Candidate Harold Kob—Part 1, BENCH MEMOS, NATIONAL REVIEW ONLINE, Sept. 24, 2008, http:/ /www.nationalreview.com/benchmemos/50710/obama-supreme-court-candidate-harold-koh-mdash-part-1/ed-whelan (criticizing judicial transnationalism as interpreted in Harold H. Koh, Why Transnational Law Matters, 24 PENN. ST. INT'L L. REV. 745, 749-50 (2006)).

${ }^{54}$ Breyer, supra note 33, at 266 (internal quotation marks omitted).

55 ViCKi C. JACKSON, CONSTITUTIONAL ENGAGEMENT In A TRANSNATIONAL ERA 115 (2009); see also Vicki C. Jackson, Constitutional Comparisons: Convergence, Resistance, Engagement, 119 HARV. L. REV. 109 (2005).

${ }^{56}$ RONALD J. KROTOSZYNSKI, JR., THE FIRST AMENDMENT IN CROSS-CUlTuRAL Perspective 51-52, 137-38 (2006); Frederick Schauer, The Exceptional First Amendment, in AMERICAN EXCEPTIONALISM AND HumAn Rights 29, 32-38 (Michael Ignatieff ed., 2005). See also Doe v. Michigan, 721 F. Supp. 852, 860-67 (E.D. Mich 1989) (discussing the various restrictions on free speech allowed by U.S. Courts under the First Amendment).
} 
One of the greatest gifts my mother ever gave me was when I was in kindergarten and I told her that everyone else was allowed to go to a friend's house after school without getting permission first except me. She said, "Now is a good time for you to learn that that reason will never work in our family. If there's a reason that something is right for us, I want to hear about it. But what everyone else is doing is never a reason for us to do it." ${ }^{57}$

My sister reflected:

What an utterly liberating idea. I never thought about trying to be like everyone else again. Now that backfired a little on my mother when she tried to tell me that everyone else wears shoes at their wedding, but other than that, we've both been very happy with it. ${ }^{58}$

I do not mean to minimize concerns about peer pressure or influence but instead to emphasize that confidence in who we are, what our values and traditions are, and how we interpret them over time stems from a source deeper than a refusal to look at what others do.

\section{B. DEFENSE OF AMERICAN EXCEPTIONALISM}

Announcement of American difference, however, is a further reason for the resistance to judicial consideration of foreign or international sources. The view of American uniqueness has roots in ideas from the Puritans, ideals of the Revolution, comments by observers like Alexis de Tocqueville,59 and visions of leaders like Abraham Lincoln, whose Gettysburg Address locates America as a nation "conceived in liberty, and dedicated to the proposition that all men are created equal." 60 After the fall of the Soviet Union, American exceptionalism also became associated with recognition of the nation as the last superpower, and some have argued that as the United States has been expected to play-and is often playing - the leading role in many international affairs, this country should be understood as an "exception" to the

${ }^{57}$ Nell Minow, Sermon delivered at Beth El Hebrew Congregation, Alexandra, Virginia 4 (Apr. $30,2010)$ (transcript on file with the Harvard International Law Journal).

${ }^{58} \mathrm{Id}$.

59 Alexis de Tocqueville, Democracy in America (Phillips Bradley ed., Henry Reeve trans., Alfred A. Knopf 1987) (1831).

${ }^{60}$ Abraham Lincoln, President of the United States, Gettysburg Address (Nov. 19, 1863) in The Collected Works of Abraham Lincoln (Ray P. Basler ed., 1953). See also Seymour MARTIN Lipset, AMERICAN EXCEPTIONALISM: A DOUbLE-EDGED SwORD 31 (1997) (“G. K. Chesterton put it: 'America is the only nation in the world that is founded on a creed. That creed is set forth with dogmatic and even theological lucidity in the Declaration of Independence. ..."”) (citations omitted). 
law of nations. Some make this claim affirmatively and others do so critically. ${ }^{61}$ In this context, reference to international law in decisions by American judges can be fraught with political charge, especially if it seems to signal adherence to international documents outside the official process of treaty agreement involving the Congress and the President.

For some, reference to foreign sources in Justice Kennedy's opinion for the fiveJustice majority striking down the death penalty for crimes committed by juveniles in Roper $v$. Simmons is especially controversial because even the majority acknowledged that "when the Senate ratified the International Covenant on Civil and Political Rights ... it did so subject to the President's proposed reservation regarding Article 6(5) of that treaty, which prohibits capital punishment for juveniles." 62 Justice Kennedy's consideration of practices by other nations thus, to some, looked like an end run around that treaty process. It is worth noting, however, that Justice Kennedy's opinion expressly interprets United States law, namely, the "cruel and unusual punishment" language in the Eighth Amendment of our Constitution, and considers foreign practice only alongside practices within our states and expert opinions within the United States as data to assess, as our Eighth Amendment directs, whether punishment is "cruel and unusual." 63 The relevance of the law of other nations is only as provided by United States law that itself directs judges to consider what is or has become "cruel and unusual."

The issue of American exceptionalism arises additionally with regard to international legal sources, and the clear rule is that the United States is bound by international law when that law has been duly incorporated into U.S. law, pursuant to our own procedures for doing so. One of the treaties we have not signed establishes the International Criminal Court (technically: President Bill Clinton signed the governing Rome Statute, President George Bush "unsigned" it, and Congress has never ratified it). ${ }^{64}$ U.S. critics assail this court-empowered to investigate and prosecute crimes against humanity, war crimes, and genocide - as an infringement of national sovereignty, as operating with vague and unaccountable power, and as subject to politically motivated prosecutions. ${ }^{65}$ It does pose the unusual feature that even nations that have not signed onto the court could face prosecutions if the situation involving an alleged international crime within the court's jurisdiction is referred to the ICC prosecutor by the United Nations Security Council under Chapter

\footnotetext{
${ }^{61}$ See, e.g., Discussion among Neal K. Katyal, Michael S. Paulsen, David B. Rivkin, Jr., Nadine Strossen, and Steven G. Calabresi, The Federalist Society, American Exceptionalism, the War on Terror and the Rule of Law in the Islamic World (Nov. 17, 2007), available at http://www.fed-soc.org/publications/pubID.460/pub_detail.asp; AMERICAN EXCEPTIONALISM AND HUMAN RIGHTS (Michael Ignatieff ed., 2005).

62 Roper, 543 U.S. at 567.

${ }^{63} \mathrm{Id}$. at $276-78$.

64 See Braced for the Aftershock, ECONOMIST, Mar. 5, 2009, at 66.

${ }^{65}$ John Bolton, Speech Two: Reject and Oppose the International Criminal Court, in TOWARD AN INTERNATIONAL CRIMINAL COURT? 37, 43-45, 47 (Alton Frye ed. 1999).
} 
VII of the Charter of the United Nations. ${ }^{66}$ The United States has itself embraced the Charter of the United Nations, so this provision is itself consistent with the law of the United States. That the United States holds a veto at the United Nations Security Council should be some reassurance that checks exist to protect the United States. ${ }^{67}$ But with calls for war crimes prosecutions against various officials in the United States for incidents ranging from the conflicts in Vietnam to the conflict in Iraq, these concerns could contribute to the heat over reference to international sources by the United States judiciary.

The proper resolution of this matter, once more, is to be found in the directives of U.S. law itself. In a series of recent decisions, the U.S. Supreme Court addressed the place of international law as a limit to the conduct of the executive branch and clearly reinforced this ground rule: where the United States has made international law part of our domestic legal system, it is binding and enforceable law inside the country, even against the executive during a time of armed conflict. Hence, in Hamdan $v$. Rumsfeld, the Court found fatal defects in the military commissions established during the administration of George W. Bush to hold trials for detainees at Guantanamo Bay because their structures and procedures violated two sources of U.S. law: the Uniform Code of Military Justice and Common Article 3 of the Geneva Conventions, signed in 1949 and codified in U.S. law and ensuring detainees a "regularly constituted court affording all the judicial guarantees which are recognized as indispensable by civilized peoples." ${ }^{6} 8$ In his concurring opinion, producing the fifth vote for this view, Justice Kennedy reasoned:

The terms of this general standard are yet to be elaborated and further defined, but Congress has required compliance with it by referring to the "law of war" in \$821. The Court correctly concludes that the military commission here does not comply with this provision.

Common Article 3's standard of a "regularly constituted court affording all the judicial guarantees which are recognized as indispensable by civilized peoples," . . . supports, at the least, a uniformity principle....

\footnotetext{
${ }^{66}$ Rome Statute of the International Criminal Court art. 13(b), July 12, 1998, 2187 U.N.T.S. 900 [hereinafter Rome Statute]. A nonstate party may also consent to ICC jurisdiction over crimes committed within its territory or over its nationals. Id. at art. 12.

${ }^{67}$ In addition, under the "complementarity" provision, should any case arise from the conduct of a United States national, the case is inadmissible before the ICC if the case "is being investigated or prosecuted" within the United States or if it "has been investigated" here and the State "has decided not to prosecute the person concerned, unless the decision resulted from the unwillingness or inability of the State genuinely to prosecute." Id., arts. 17(1)(a), 17(1)(b).

${ }^{68}$ Hamdan v. Rumsfeld, 548 U.S. 557, 642 (2006) (Kennedy, J. concurring) (quoting Geneva Convention (III) Relative to the Treatment of Prisoners of War, Aug. 12, 1949, 6 U.S.T. at 3318).
} 


\begin{abstract}
Absent more concrete statutory guidance, this historical and statutory background-which suggests that some practical need must justify deviations from the court-martial model-informs the understanding of which military courts are "regularly constituted" under United States law. ${ }^{69}$
\end{abstract}

Explicit Congressional authority would be necessary before the executive could bypass these otherwise existing U.S. norms. No claim of American exceptionalism can give the President of the United States unilateral authority to suspend the Geneva Conventions; ${ }^{70}$ for those who care about the capacity of the United States to operate apart from developments in international law, the internal domestic structures of the United States Constitution-notably, congressional action, subject to presidential veto and judicial review-provide the proper avenues.

\title{
C. CUSTOMARY INTERNATIONAL LAW
}

Heated concerns over bypassing domestic legal structures lie behind the specific objection to judicial application of what is known as "customary international law." Understanding those concerns can help explain some of the anxieties about judicial application of international law. "Customary international law" can be defined as "rules of law derived from the consistent conduct of States acting out of the belief that the law required them to act in that way." "71 Analogous in some ways to the common law in the Anglo-American tradition, customary international law-which has, according to observers such as the authors of the 1987 Restatement (Third) of Foreign Relations Law of the United States, long included the international crimes of slavery, genocide, and war crimes, as well as the principles of immunity for visiting heads of state and the right to humanitarian intervention - thought by some to be

${ }^{69} \mathrm{Id}$. at 644 .

${ }^{70}$ President Bush had so claimed. See Memorandum from George W. Bush, President of the United States to The Vice President, the Sec'y of State, the Sec'y of Def., the Attorney Gen., Chief of Staff to the President, Dir. Of Cent. Intelligence, Assistant to the President for Nat'l Sec. Affairs \& Chairman of the Joint Chiefs of Staff (Feb. 7, 2002), reprinted in MARK DANNER, Torture And Truth: America, Abu GHraib, AND the War on Terror 105 (2004). See also Memorandum from Alberto R. Gonzales, Attorney Gen., to George W. Bush, President of the United States (Jan. 25, 2002), reprinted in DANNER, supra note 70, at 83. By their terms, common art. III of the Geneva Conventions cannot be repudiated by a signatory during an ongoing conflict. GENEVA CONVENTION [NO III] RELATIVE TO THE TREATMENT OF PrisONERS OF WAR, Aug. 12, 1949, 6 U.S.T. 3316, 75 U.N.T.S. 135.

${ }^{71}$ Shabtai Rosenne, Practice and Methods of International Law 55 (1984). Shabtai

Rosenne is the former Ambassador of Israel to the United Nations and a leading expert on international courts. See also JeAn-MArie HenCKAERTS \& Louise Doswald-BECK, 1 CUSTOMARY INTERNATIONAL HUMANITARIAN LAW xxxi-xlii (2005) (exploring customary international law which is not written and which is reflected in state practice and conviction in the international community that such practice is required as a matter of law). 
binding, not merely advisory. ${ }^{72}$ The Restatement itself, written by American law professors Louis Henkin, Andreas Lowenfeld, Louis Sohn, and Detlev Vagts, was the first effort to assert inclusion of customary international law within the U.S. federal law; the prior edition has indicated that its status was an open question. ${ }^{73}$ In a powerful law review article published in 1997, law professors Curtis Bradley and Jack Goldsmith argued against treating customary international law as part of U.S. law, in part by showing the absence of any actual judicial opinion or federal statute clearly making customary international law part of U.S. law. ${ }^{74}$

Two sources of U.S. law make customary international law pertinent. The first is the United Nations Charter-over which the United States played a key role and to which our nation subscribes. The United Nations Charter includes a provision directing the International Court of Justice to apply "international custom, as evidence of a general practice accepted as law." 75 Discerned in assessments of general, consistent, and widespread practice, this source of norms has governed relations among diplomats and rules of war. The second instance is the Alien Tort Statute, enacted as a clause of the Judiciary Act of 1789, directing that federal district courts "shall also have cognizance, concurrent with the courts of the several States, or the circuit courts, as the case may be, of all causes where an alien sues for a tort only in violation of the law of nations or a treaty of the United States." ${ }^{\prime 76}$ Ignored or neglected for centuries, this provision has recently been deployed as a vehicle for international human rights litigation in U.S. federal courts. In 1980, the Federal Court of Appeals for the Second Circuit found jurisdiction and held that deliberate torture perpetrated under color of official authority "violates universally accepted norms of the international law of human rights, regardless of the nationality of the parties"and under that holding, the court ruled that U.S. federal courts could hear cases alleging violations of public international law or treaties brought by non-U.S. citizens even for conduct occurring outside the United States. ${ }^{77}$ Ultimately in this case, a federal court announced civil damages liability against the former police inspector general of Paraguay following the kidnapping and torturing of a 17-year-old son of the plaintiff in reaction to his father's political activities. ${ }^{78}$

With this case and its progeny, as well as assertions by some human rights advocates that customary international law constrains the executive branch of the United States, customary international law has generated controversy. Why should the federal courts address extra-territorial matters? They impose burdens of work;

\footnotetext{
72 RESTATEMENT (THIRD) OF THE FOREIGN RELATIONS LAW OF THE UNITED STATES $\int 404$ (1987).

${ }^{73}$ Curtis A. Bradley \& Jack L. Goldsmith, Customary International Law as Federal Common Law: A Critique of the Modern Position, 110 HARV. L. REV. 815, 834-36 (1997).

${ }^{74} \mathrm{Id}$. at $849-70$.

75 The Statute of the International Court of Justice, annex to the U.N. Charter, art. 38(1)(b). ${ }^{76}$ Judiciary Act of 1789, ch. 20, \ 9, 1 Stat. 73, 77 (current version at 28 U.S.C. \ 1350) ("The district courts shall have original jurisdiction of any civil action by an alien for a tort only, committed in violation of the law of nations or a treaty of the United States.").

${ }^{77}$ Filartiga v. Pena-Irala, 630 F.2d 876, 878 (2d Cir. 1980).

${ }^{78}$ Id.
} 
they strain the courts' expertise; and they may unmoor the courts from U.S. law, some may object. These objections may grow in the face of assertions that customary international law is evolving to include economic and social rights, to prohibit the death penalty, and to regulate discrimination on the basis of sexual orientation. ${ }^{79}$ Professors Bradley and Goldsmith note that customary international law is now articulated not only by actual practices of states but by treaties, resolutions, and views of academics. ${ }^{80}$ They also note how customary international law is growing rapidly and addressing topics - such as labor organizing, primary education, and hate speech-historically treated only by domestic law. ${ }^{81}$ Other examples claimed to be customary international law include the protection of refugees from being sent back to places where their lives or liberties are in jeopardy; immunities for visiting foreign heads of state, a right of humanitarian intervention, and prohibitions of slavery, genocide, and crimes against humanity, although no one claims that these were consistent practices among civilized nations at the time of the founding of the United States. Very fair questions arise, thus, over what counts as consistent practice, who decides, and why practices never explicitly endorsed or embraced within the United States come to trump rules adopted pursuant to the legislative, judicial, and executive practices of U.S. states and the nation. ${ }^{82}$

Among the powerful critiques developed by Professors Bradley and Goldsmith is one telling argument that portrays dramatic shifts in prevailing understandings of law itself within the United States. They note how for a time customary international law was viewed by judges, scholars, and lawyers in this country as part of "general common law," inherited from England or simply the "law of the land" with no attention to its source in particular judicial or legislative authority. ${ }^{83}$ This fit a dominant pattern before 1938, when even federal courts could claim to be simply finding the general common law of torts or contracts even if that meant contradicting what a state law said. Oliver Wendell Holmes, Jr., with disparagement called this conception of general common law that of "a transcendental body of law outside of any particular State" 84 and he instead argued that the common law evolves and reflects the interests and times of those articulating it. ${ }^{85}$ So rather than one universal body of law, the common law reflected rules and decisions created by particular decision-makers. In its 1938 decision in Erie Railroad Co. v. Tompkins, the Supreme Court embraced this view and rejected assertions by federal courts of a power to announce general common law; "law in the sense in which courts speak of it today does not exist without some definite authority behind it" and hence "[e]xcept in matters governed by the Federal Constitution or by Acts of Congress, the law to be

\footnotetext{
79 See Bradley \& Goldsmith, supra note 73 , at 818.

${ }^{80} I d$. at 839.

${ }^{81} I d$. at $840-42$.

82 See Bradley \& Goldsmith, supra note 73 , at 838, 857-59, 870-76.

${ }^{83} \mathrm{Id}$. at $822-23$.

${ }^{84}$ Black \& White Taxicab Transfer Co. v. Brown \& Yellow Taxicab \& Transfer Co., 276 U.S. 518, 533 (1928) (Holmes, Jr., J. dissenting).

85 Oliver Wendell Holmes, JR., The COMmOn LAW (1881), available at

http://pds.lib.harvard.edu/pds/view/10253629?.
} 
applied in any case is the law of the State." 86 Scholars gradually recognized that this knocked the legs out from under federal court articulations of customary international law as well, and that is the argument that Bradley and Goldsmith emphasized. ${ }^{87}$ Hence, a federal court cannot apply customary international law "in the absence of some domestic authorization to do so." 88

The U.S. Supreme Court actually had a chance to weigh in on this question-and the status of customary international law in federal courts-in a case in which a Mexican citizen brought a claim under the Alien Tort Statute asserting false arrest by U.S. Drug Enforcement Agency and a Mexican national hired to help the U.S. government. A district court and the Court of Appeals for the Ninth Circuit ruled that the Alien Tort Statute created a private cause of action for the Mexican citizen to claim a violation of international law due to the arbitrary arrest and detention against Jose Francisco Sosa, the Mexican citizen hired to help the U.S. agency. Defendant Sosa argued that U.S. courts have no authority to announce or apply customary international law; the plaintiff argued that not only do the federal courts have that power but it extended to the instance of false arrest he claimed. The Supreme Court struck a middle course. Using a close study of evidence about how the framers of the Constitution approached international law, the Supreme Court unanimously ruled that the international common law claims authorized for enforcement in the federal courts do not include the claim in this case, and federal courts should not recognize as claims violations of international law norms "with less definite content and acceptance among civilized nations than the $18^{\text {th }}$-century paradigms familiar" when the Alien Tort Statute was enacted in 1789—-such as those against piracy, prohibiting offenses against ambassadors, and ensuring safe conduct into or out of a country, whether during war, truce, or peacetime. ${ }^{89}$

Justice Scalia concurred in the result in the case and concurred in the assessment of the historical understanding. But, in a separate opinion, Justice Scalia asserted that recent developments-including the post-Erie treatment of common law-preclude the federal courts from recognizing any further developments in international common law. He objected that "the law of nations, redefined to mean the consensus of states on any subject" is merely "a $20^{\text {th }}$-century invention of internationalist law professors and human rights advocates" inconsistent with the intent of the Constitution's framers and the democratic project." 90 Nonetheless, even Justice Scalia did not dispute that Congress in 1789 authorized federal courts to enforce a small number of international norms even without further specific authorization by

${ }^{86}$ Erie R.R. Co. v. Tompkins, 304 U.S. 64, 78-79 (1938).

${ }^{87}$ Bradley \& Goldsmith, supra note 73 , at 827-28, 846-47, 852.

${ }^{88} \mathrm{Id}$. at 853 .

89 Sosa, 542 U.S. at 732. The Court noted that the Untied States announced their reception of the "law of nations" at the time of the Declaration of Independence, and that included, as summarized ultimately by Blackstone, violation of safe conducts, infringement of the rights of ambassadors, and piracy. Id. at 713-14. One historical inquiry suggests that the framers had in mind only safe conducts, not piracy or ambassadorial infringements. Thomas H. Lee, The Safe-Conduct Theory of the Alien Tort Statute, 106 CoLUM. L. REV. 830 (2006).

90 Sosa, 542 U.S. at 749-50 (Scalia, J., concurring in part and concurring in the judgment). 
Congress. ${ }^{91}$ A six-Justice majority kept the door open to new statements of federal common law by federal courts, given two centuries of acknowledgment of international law by the United States and the supplemental authority given by Congress to permit judicial consideration of torture victim cases. ${ }^{92}$ But even this group of Justices emphasized, as I already mentioned, that "federal courts should not recognize private claims under federal common law for violations of any international law norm with less definite content and acceptance among civilized nations than the historical paradigms familiar" when the Judiciary Act of 1789 was enacted. ${ }^{93}$ And in addition, cautioned the Court, practical consequences of making a claim available to litigants should be considered. ${ }^{94}$

Because the subject of customary international law remains one where federal courts might exercise some limited and restrained discretion, the topic could generate anxieties about federal court consideration of international law. The historical shifts in prevailing understandings of the nature of law's development and authority-and the increasing recognition that judges do not merely discover pre-existing law, they help create it-may increase concerns over the sources judges can consult. The Supreme Court has tethered consultation of customary international law to traditions and understandings in this country in 1789. This seems a sound precaution given growing evidence that first actors in announcing developments in customary international law may themselves retreat or alter their positions over time. ${ }^{95}$ Where there are disagreements across nations about the content of customary international law, it seems almost definitional that the topic in question does not yield a norm of such general practice and acceptance as to rise to the level of customary international law.

In exploring the sources of concern over judicial consultation of foreign and international law, I have suggested worries about customary international law, risks to America given politically motivated uses of law, and fears of being taken over or losing control. To be frank, those who raise these concerns are likely more worried about what others will do than about themselves. But I hope that the recent history I have recounted gives assurance that the Supreme Court has affirmed rigorous adherence to American law and traditions when the Justices turn to foreign or international law and has emphasized restraint even then.

\footnotetext{
${ }^{91}$ Id. at 728-30 (discussing Scalia, J. concurring opinion and referring back to sections I and II, endorsed by Justice Scalia).

${ }^{92}$ Id. at $724-25$.

${ }^{3} I$ Id. at 732 .

${ }^{94} \mathrm{Id}$. at $732-33$.

95 See, e.g., Máximo Langer, The Diplomacy of Universal Jurisdiction: The Regulating Role of the Political Branches in the Transnational Prosecution of International Crimes, 47-52 (Harvard Law School Faculty Workshop, Working Paper, 2010) (discussing developments in universal jurisdiction) (on file with Harvard International Law Journal).
} 


\section{RECLAIMING THE CHANCE TO LEARN}

Those who object to references to foreign or international law even when U.S. law directs attention to these sources run risks of inciting anxieties and fears, as the death threats to Justices Ginsburg and O'Connor indicate. There are other costs that spread beyond judges and courts.

Neglecting developments in international and comparative law could vitiate the vitality, nimbleness, and effectiveness of American law or simply leave us without the best tools and insights as we design and run institutions, pass legislation, and work to govern ourselves.

Consider two examples of extra-domestic-and extra-judicial-learning that would be helpful; the absence of which would be a loss.

First, regulators, citizens, and indeed anyone interested in governance could learn about emerging forms of what is called "soft law" in the context of the European Union. Unlike government-issued rules that carry sanctions, enforceable by courts or agencies, soft law includes voluntary standards that depend on consensual action, and which are embraced by private actors and also informal institutions. ${ }^{96}$ Soft law can proceed through private and voluntary codes, certification and labeling systems, or transparency obligations placed on government where the disclosure of information deters misconduct and empowers observers to monitor government action. ${ }^{97}$ And, as summarized by John Kirton and Michael Trebilcock, soft law offers the advantages of "timely action when governments are stalemated; bottom-up initiatives that bring additional legitimacy, expertise, and other resources for making and enforcing new norms and standards; and an effective means for direct civil society participation in global governance."98 In trade, labor relations, environmental protection, and other fields, these techniques can elicit changes in behavior, attract cooperation, and also at times work as a precursor to or substitute for "hard law" with sanctions. These kinds of devices pervade international law and also identify tools that are often useful within a country, state, or town. ${ }^{99}$

Of course, we use some of these devices already, both domestically and in our international ties. But learning about developments elsewhere could offer new tools and refinements even while helping us clarify how law works. It is easy to emphasize that foreign and international legal materials-analogous to soft law--represent no

96 See John J. Kirton \& Michael J. Trebilcock, Introduction: Hard Choices and Soft Law in Sustainable Global Governance, in HARD CHOICES, SOFT LAW: VOLUNTARY STANDARDS IN GLOBAL TRADE, ENVIRONMENT AND SOCIAL GOVERnANCE 3, 9 (John J. Kirton \& Michael J. Trebilcock eds., 2004); MARY ElLEN O’CONNELl, THE POWER AND PurPose OF INTERNATIONAL LAW: INSIGHTS FROM THE THEORY AND PRACTICE OF ENFORCEMENT 12 (2008).

${ }_{97}$ See Kirton \& Trebilcock, supra note 96, at 10.

${ }^{98} I d$. at 5.

99 See Gerda Falkner, et al., Complying with Europe: EU Harmonisation and Soft Law in the Member States 179-80 (2005); Dinah Shelton, Soft Law, in Routledge Handbook of International Law 68 (David Armstrong ed., 2009); David M. Trubek, Patrick Cottrell \& Mark Nance, 'Soft Law', 'Hard Law' and EU Integration, in Law and New Governance in the EU and US 65, 69 (Gráinne De Búrca \& Joanne Scott eds., 2006). 
binding force within the United States, except where American law itself endorses, incorporates, or calls for consultation of international or foreign law. Nonbinding authorities, including law reviews, scholarly treatises, and judgments of sister circuit courts are often and widely consulted. Especially in issues of first impression or evolving legal norms, consultation of nonbinding sources can be instructive and clarifying though never binding.

A second topic offering potentially useful learning to lawyers, judges, and citizens in the United States is the International Criminal Court. It is the institutional design that offers instruction here. Any worries about prosecutions of United States citizens are not only unwarranted but they also risk obscuring fascinating features of that experiment that might offer intriguing ideas for domestic work here. Chief among them is the idea of complementarity, built into the Court: the Court defers to actions within nations and in fact loses the ability to proceed with a case if the case "is being investigated or prosecuted" within a country having jurisdiction over it or even if it "has been investigated" here and the State "has decided not to prosecute the person concerned, unless the decision resulted from the unwillingness or inability of the State genuinely to prosecute."100 This device has several consequences. It puts power in the hands of individual nations to avoid ICC action - if only the individual nation takes up the investigation of the matter otherwise headed to the ICC. It thereby creates a device for limiting the ICC's business and power. It also creates an incentive for increasing capacity and political will in individual nations for enforcing the norms against genocide and crimes against humanity. It preserves decentralization and national sovereignty in ways that might offer models on some matters for the relationships between the national and state governments within the United States, between Indian Tribes and the United States, between government and nongovernmental entities, or in other instances where multiple agents may have an interest in a given matter. A dean might try this with students, or a parent might even try this with a child-I'll check into your conduct unless you do so and do so credibly.

The complementarity device of the ICC is simply one example of international legal materials offering potential instruction to people in the United States-not because it is our law but because it offers an approach to issues of institutional design that we often face. Moreover, we as Americans who contributed so much to modern international law remain involved in it. Even Americans who report skepticism about the efficiency of the UN respond very positively to the recommendations of the UN. 101

One last thought: we might actually learn something from an instance about which I think there is considerable pride in this country. Our Supreme Court's landmark decision, Brown v. Board of Education, is a legal moment about which our nation is justifiably proud. However partial and limited is the fulfillment of its ultimate vision of racial integration, Brown's rejection of "separate but equal" schools spurred the end of segregation in retail stores, theaters, swimming pools, and

\footnotetext{
100 Rome Statute art. 17(1)(a), 17(1)(b).

101 Katerina Linos, How International Norms Shape Voter Choices, 103 AM. SOC’Y INT'L L. PROC. 10, 11 (forthcoming 2010).
} 
employment, though often only after a struggle and legislative or litigated reforms. ${ }^{102}$ The steps from Jim Crow segregation to the election of President Barack Obama were many and nonlinear, but Brown played a role in mobilizing changes in ideas as well as in practices and opportunities. Brown's influence inside schools but outside of the context of race has profoundly altered the discussions and treatment of gender, disability, language, ethnicity, and national origin, with further changes in the way educational and life opportunities of students are affected by their sexual orientation, religion, economic class, or status as Native Hawai'ians or Native Americans. ${ }^{103}$ Well beyond schooling, Brown and the efforts surrounding it have created the model for social and legal reforms in the United States on behalf of girls and women, persons with disabilities, members of religious minorities, and advocates for economic justice, environmental protection, and other issues. ${ }^{104}$

As I researched my new book on Brown's influence, ${ }^{105} \mathrm{I}$ was struck by how much our landmark case and the struggle behind it have served as an evocative reference point for advocates pursuing equal opportunity and social change around the world. Advocates in Northern Ireland, South Africa, India, and Eastern Europe have pointed to Brown in their own efforts to use law to overcome social division within educational systems and even in initiatives addressing social hierarchy and exclusion without connection to race or education. ${ }^{13}$ Although this international perspective echoes Brown's mixed legacy in actually realizing equal opportunity in practice, looking across the world, it is undeniable that Chief Justice Warren's opinion for a unanimous Supreme Court has become a powerful resource for change agents everywhere.

Brown v. Board of Education has played a prominent role in efforts both to combat this segregated education system and to transition away from the apartheid regime more generally. In 1958, Britain's Prime Minister Harold Macmillian cited Brown while critiquing apartheid in an address to South Africa's Parliament. 106 During the 1980s, two lawyers who worked closely with Thurgood Marshall on Brown v. Board of Education assisted lawyers in South Africa to develop judicial strategies to terminate

102 See, e.g., JefF Wiltse, CONTESTEd WATERs: A Social History OF SWIMMing PoOLS IN AMERICA (2007); RiCHARD C. CORTNER, CIVIL RigHTS AND PubliC ACCOMMODATIONS: THE HEART OF ATLANTA MOTEL AND MCCLUNG CASES (2001). See generally GARY GERSTLE, American Crucible: RaCE AND NATION In the Twentieth CENTURy (2001); MiChaEL J. KLARMAN, UnFINISHED Business: RACIAL EQUALITY IN AMERICAN History 160-203 (2007); RiCHARD WORMSER, THE RiSE AND FALL OF JIM CROW (2003). 103 See MARTHA MinOW, In BROWN'S WAKE: LEGACIES OF AMERICA's CONSTITUTIONAL LANDMARK 33-83, 96-108 (2010).

104 See, e.g., Beverly Wright, The Deep South Center for Environmental Justice: Education and Empowerment for an Engaged Citizenry, 8 DIVERSITY DIGEST 11 (2004), www.diversityweb.org/Digest/vol8no2/wright.cfm; David S. Meyer \& Steven A. Boutcher, Signals and Spillover: Brown v. Board of Education and other Social Movements, 5 PERSP. ON POL. 81 (2007).

105 MinOw, supra note 103.

106 See Anthony Lester, Brown v. Board of Education Overseas, 148 PROC. AM. PHIL. SOC'Y 455, 459 (2004). 
apartheid. ${ }^{107}$ After the fall of apartheid and the creation of a new constitutional regime, the South African Constitutional Court has repeatedly cited Brown v. Board of Education in cases. For the case of In re The School Education Bill of 1995, the Court relied on Brown in discussing the important role of education in developing and maintaining a democratic society, but reflected the history of South Africa and the global human rights movement in rejecting the claim that the government had a constitutional duty to establish or fund Afrikaans schools while recognizing the right of private groups to maintain such schools. ${ }^{108}$ One author argues that the tensions over school desegregation and affirmative action in the United States influenced drafters of the South African Constitution in their decision to shield remedial uses of racial categories from constitutional challenge. ${ }^{109}$

And last October, the South African Constitutional Court worked to accommodate language rights while tackling ongoing exclusion of black South Africans from educational opportunities. An Afrikaans-language school had extra spaces and black South Africans wanted access, but the school asserted a right to instruct only in Afrikaans. The Constitutional Court acknowledged the constitutional right to be taught in an official language of one's choice but directed the school's own governing body to reassess its language policy and provide sufficient spaces for English learners for the coming school year. ${ }^{110}$ Affirming equality as respect for the language of one's own choice in this case involved protecting a minority language of the historically privileged group; ${ }^{111}$ the Court then expressly pointed to the

107 See Richard J. Goldstone \& Brian Ray, The International Legacy of Brown v. Board of Education, 35 MCGEORGE L. REV. 105, 114 (2004) (discussing efforts by Constance Baker Motley and Jack Greenberg).

${ }_{108}$ In re Dispute Concerning the Constitutionality of Certain Provisions of the School Education Bill of 1995, 1996 (3) SA 165 (CC) at 9 47-52 (S. Afr.); see also Penelope Andrews, Perspectives on Brown:

The South African Experience, 49 N.Y.L. SCH. L. REV. 1155, 1165-67 (2005); Rassie Malherbe, A Fresh Start I: Education Rights in South Africa, 4 EUR. J. FOR EDUC. L. \& POL'Y 49, 50-51 (2000). Courts in other countries have also referenced Brown for the general proposition that education is pivotal in a democratic society. See, e.g., R. v. Jones, [1986] 2 S.C.R. 284, \ 22

(Can.); see also Goldstone \& Ray, supra note 107, at 117-18 (discussing case in Trinidad and Tobago).

109 Andrews, supra note 108, at 1158-65. See generally MARK S. KEnde, CONSTITUTIONAL RigHTS IN TwO WORLDS: SOUTH AFriCA AND THE UNITED STATES (2009).

${ }^{110}$ Head of Dep't: Mpumalanga Dep't of Educ. v. Ermelo, (CCT 40/09) [2009] ZACC 32 (Oct. 14, 2009) (Saflii), available at http://www.saflii.org/za/cases/ZACC/2009/32.pdf (unpublished).

111 The case thus offers a striking contrast to Lau v. Nichols, 414 U.S. 563 (1974), in which a minority immigrant group of Chinese-speaking students successfully argued that instruction solely in English failed to provide equal educational opportunity. See MiNOW, supra note 103, at 37-40. The historic power and resources held in the Afrikanner community complicate protection for its autonomy; but for that, the case has some similarities with issues confronted by indigenous groups at risk of forced assimilation unless they can maintain their own culture. See MiNOW, supra note 103, at 96-108. 
Constitutional design to transform public education and South African society by addressing unequal access to educational resources. ${ }^{112}$

In Eastern Europe, the European Roma Rights Center in Budapest joined with others, including Czech attorney David Strupek, in 2000 to challenge student placement practices in the Czech Republic, where a disproportionately large number of Roma children were being placed in schools for students with mental or learning disabilities rather than mainstream schools. ${ }^{113}$ Lawyers and others working on behalf of the Roma students explicitly discussed Brown and the movement surrounding it. ${ }^{114}$ They initiated a case known as D.H. as the centerpiece of the Roma rights movement's litigation strategy, ${ }^{115}$ which was designed to pursue cases that could change existing practices "through liberal and far-reaching judicial interpretation, as well as to trigger comprehensive reform of legislation." 116 D.H.- like the cases combined into Brown-focused on systematic discrimination and mindsets perpetuating second-class status for an entire group of people. Lawyers from the United States, Great Britain, and many European nations contributed to the advocacy strategy and commentary about it. ${ }^{117}$

And the European Court of Human Rights ruled in favor of the Roma applicants by a vote of thirteen to four. ${ }^{118}$ Finding the special schools offered an often inferior curriculum as well as diminished educational and employment prospects, ${ }^{119}$ and

112 Head of Dep't: Mpumalanga Dep't of Educ. v. Ermelo, (CCT 40/09) [2009] ZACC 32 at 9甲 45-47.

${ }^{113}$ European Roma Rights Centre, Strasbourg Application by Roma Challenges Racial Segregation in Czech Schools (Apr. 29, 2000), available at

http://www.errc.org/cikk.php?cikk=219.

114 William New, Remarks at the Annual Meeting of The Law and Society Association: D.H. \& Others v. C.Z.: A Narrative Analysis of Romani Education Policymaking (July 6, 2006) (transcript on file with the Harvard International Law Journal).

115 Morag Goodwin, Developments, D.H. and Others v. Czech Republic: A Major Set-back for the Development of Non-discrimination Norms in Europe, 7 GERMAN L.J. 421 (2006).

${ }^{116}$ European Roma Rights Centre Legal Activities, www.errc.org/Litigation_index.php (last visited Nov. 6, 2009), cited in Jennifer Devroye, The Case of D.H. and Others v. the Czech Republic, 7 Nw. U. J. INT'L HuM. RTS. 81 (2009).

117 See Bob Hepple, The European Legacy of Brown v. Board of Education, 2006 U. ILL. L. REV. 605 (2006). Sir Bob Hepple, a distinguished English law professor, was born in South Africa and is a frequent lecturer there.

118 Grand Chamber Judgment, Case of D.H. \& Others v. Czech Republic, App. No. 57325/00, 47 Eur. H.R. Rep. 3 (2008), available at http://www.echr.coe.int/echr/en/hudoc/ [hereinafter D.H. Grand Chamber Judgment]. The decision is notable in clarifying that, at least in the context of education, the European Convention on Human Rights applies not only to cases of individual discrimination but also to systemic discrimination; that a prima facie case of discrimination can be shown through evidence of disproportionately negative effects on one racial group in the application of an apparently neutral rule; that statistical evidence can show such a prima facie case, and upon the showing of a prima facie case, the burden of proof shifts to the responding party to try to demonstrate that the rule or practice was objectively and reasonably justified. $I d$.

${ }^{119} \mathrm{Id}$. at 9207. 
finding that the placement in special schools likely increased stigma for Roma children, the Grand Chamber quoted, with approval, the European Commissioner for Human Rights, who said that "segregated education denies both the Roma and nonRoma children the chance to know each other and to learn to live as equal citizens." 120 The Grand Chamber cited research from the United States about racial inequity in special education, ${ }^{121}$ noting the negative effects of early tracking. ${ }^{122}$ It located its judgment in the context of sources from the Council of Europe, ${ }^{123}$ including European Community law and practice concerning indirect discrimination and disparate impact of tests on minority populations; ${ }^{124}$ United Nations materials; ${ }^{125}$ and a set of "other sources," including the U.S. Supreme Court's interpretation of the 1964 Civil Rights Act, allowing evidence of the disparate racial impact of a test as evidence of racial discrimination. ${ }^{126}$ The European Court ultimately ruled that demonstration of invidious intention was not necessary to show a pattern of separation and disadvantage for children from one background and in this dimension, struck out on a path quite different from the constitutional interpretation of the U.S. Supreme Court, which demands proof of intentional discrimination to establish a violation of the U.S. Constitution.

One more echo of Brown can be heard in Northern Ireland which has long been divided between "controlled" schools—which are government run, have Protestant roots, and serve about 50 percent of the students—and "managed" schools, which are maintained by Catholic organizations and educate about 45 percent of the children. Historically, these separate school systems have taught contrasting versions of regional history and as a result have not reduced but have contributed to the tensions and violence of "the Troubles," which begin in the 1960s and have continued even after the Belfast agreement of 1998. In the 1980s, a group of parents started the Northern Ireland Council for Integrated Education as a voluntary organization to develop schools that would bring together students from the two communities. With government aid, the Council allows parents to launch new, integrated schools; the Council also developed a procedure by which parents could vote to convert an existing school into an integrated school. ${ }^{127}$ These schools give general instruction in Christianity rather than strict instruction in Protestantism or Catholicism. ${ }^{128}$ The

\footnotetext{
${ }^{120} \mathrm{Id}$. at 50 (quoting the commissioner for human rights).

${ }^{121} \mathrm{Id}$. at 44 (citing Daniel J. Losen \& Gary Orfield, Introduction, in RACIAL INEQUITY IN

SPECIAL EDUCATION xv (Daniel J. Losen \& Gary Orfield eds., 2002)).

${ }^{122} \mathrm{Id}$. at 9 甲 $52-53$.

${ }^{123}$ Id. at $1954-80$ (citing recommendations adopted by the Committee of Ministers of Council of Europe, the Parliamentary Assembly of the Council of Europe, the Framework Convention for the Protection of National Minorities, and the Commissioner for Human Rights).

${ }^{124} I d$. at 9 甲 81-91.

125 Id. at 9 \ 92-102.

${ }^{126}$ Id. at 107 (citing Griggs v. Duke Power Co., 401 U.S. 424 (1971)).

${ }^{127}$ FAITH SCHOOLS: CONSENSUS OR CONFLICT? 159 (Roy Gardner, Jo Cairns \& Dennis Lawton eds., 2005).

128 See Northern Ireland Council for Integrated Education, What Is Integrated Education? http://www.nicie.org/aboutus/default.asp?id=30 (last visited Aug. 6, 2010).
} 
Department of Education incorporates such schools only after they show sufficient enrollment and a waiting list for preschool. ${ }^{29}$

By 2009, the Council had produced, with aid from English charitable trusts, nineteen integrated nursery schools, forty-one integrated primary schools, and twenty integrated second-level colleges_-showing impressive growth, but reaching barely five percent of the population. 130 Across the country, integrated schools have generated considerable parental demand, with long waiting lists. Perhaps by having a strategy of integrating schools only with supportive parents and starting such schools on a small scale, the project ensured from the start a base of support rather than conflict-even before the larger community conflict quieted down.

After a decade of relative peace following a process producing political powersharing, Northern Ireland experienced a spike in intergroup violence in March 2009. The murder of a Northern Irish police officer in Ulster occurred two days after the murders of two British soldiers, and a resurgence of acts of terror committed by dissident groups wracked the region. ${ }^{131}$ Johann Hari, a British journalist, suggested "Northern Ireland needs its own version of Brown v. Board of Education."132 Citing a six-year study by researchers at Queen's University, Hari noted that individuals who attended the integrated schools were "significantly more likely" to oppose sectarianism, had more friends across the divide, and identified as "Northern Irish" rather than as "British" or "Irish."133 Stressing that "[i]t's difficult to caricature people you've known since you were a child: great sweeping hatreds are dissolved by the grey complexity of individual human beings," Hari marveled that " 82 percent reported that they personally support the idea of integrated schooling, and 55 percent of parents say the only reason their kids don't go to an integrated school is because" they cannot get into one. ${ }^{134}$ And taking one more page from U.S. history, this British journalist

\footnotetext{
${ }^{129}$ Colin KnOX \& PÁdraic Quirk, PeAce BuILding in Northern Ireland, IsRaEL AND SOUtH AFriCA: Transition, TRANSFORMATION AND RECONCILIATION 63-64 (2000).

${ }^{130}$ Northern Ireland Council for Integrated Education, supra note 128.

131 New Wave of Violence Grips Northern Ireland, VOANEWs (Mar. 10, 2009), http://www1.voanews.com/english/news/a-13-2009-03-10-voa30-68813047.html; Henry McDonald \& Owen Bowcott, Ulster Violence Escalates as Policeman Is Shot Dead, GuARDIAN, Mar. 10, 2009, at 1.

${ }^{132}$ Johann Hari, Northern Ireland Needs Its Own Version of "Brown vs. The Board of Education"- and Fast, HufFINGTON POST (Mar. 14, 2009), www.huffingtonpost.com/johann-hari/northernireland-needs-it_b_174939.html. Hari is a Scottish-born journalist, based in London, with the Independent; in 2008 he became the youngest person ever to be awarded the George Orwell Prize for political journalism.

${ }^{133} \mathrm{Id}$. The piece explains that among those who attended integrated schools, "politics were far more amenable to peace: Some 80 percent of Protestants favour the union with Britain, but only 65 percent of those at integrated schools do. Some 51 percent of Catholics who went to a segregated school want unification with Ireland, but only 35 percent of those from integrated schools do. The middle ground - for a devolved Northern Ireland with links to both countries, within the EU-was fatter and happier." Id. ${ }^{134} \mathrm{Id}$.
} 
concluded: "Who knows-a hefty push for school integration could yield, in a few decades, a Northern Irish Obama, carrying both sides in his veins."135

There might even be lessons to take back to the United States about the potential influence of a parent-based movement for integration. But Brown itself, as it turns out, even before the U.S. Supreme Court, reflected important influence from comparative and international concerns. The Swedish scholar Gunner Myrdal's American Dilemma, with its searing indictment of America's treatment of the "Negro," became a key citation in the Court's famous footnote 11.136 Initially, President Eisenhower showed no sympathy for the school integration project and expressed suspicion that the United Nations and international economic and social rights activists were betraying socialist or even communist leanings in supporting the brief. ${ }^{137}$ But as the United States tried to position itself as a leader in human rights and supporter of the United Nations, the Cold War orientation of Eisenhower's Republican administration gave rise to interest in ending official segregation, lynchings, and cross burnings in order to elevate the American image internationally. The Department of Justice collaborated with the State Department on an amicus brief that argued that ending racially segregated schools could terminate the Soviet critique of the tolerance of racial abuses by the U.S. system of government and thereby help combat global communism. ${ }^{138}$ Ending segregation emerged as part of a strategy to secure more influence than the Soviet Union over the "Third World." AfricanAmerican civil rights leader and journalist Roger Wilkins later recalled that ending official segregation became urgent as black ambassadors started to visit Washington, D.C. and the United Nations in New York City. ${ }^{139}$

At our best, we have learned from a global perspective; my small and I hope not too controversial thought is: judges and lawyers, citizens and residents of this country can and should continue to learn from global perspectives in order to advance the best version of ourselves.

\footnotetext{
135 Id.

136 Brown v. Board of Education, 347 U.S. 483, 494 n.11 (1954); see GUNNAR MYRDAL, AN AMERICAN Dilemma (1944); WALTER A. JACKSON, GUNNAR MYRDAL AND AMERICA'S CONSCIENCE: SOCIAL ENGINEERING AND RACIAL LIBERALISM, 1938-1987 (1990). 137 See CArol Anderson, Eyes OfF the Prize: United NATIONS AND the AFricAN AMERicAN StrugGLE FOR HuMAN Rights, 1944-1955 (2003). Anderson argues that anticommunism contributed to the narrowing of the civil rights agenda.

138 See MARY L. DudZiaK, COLD WAR Civil RightS: RACE AND THE IMAGE OF AMERICAN DEMOCRACY 99-102 (2000). See also Lester, supra note 106, at 457-59 (noting Department of Justice brief in pre-Brown civil rights cases indicating how the nation's foreign relations were embarrassed by its domestic acts of discrimination).

139 Black/White and Brown: Brown versus the Board of Education of Topeka (KTWU/Channel 11 broadcast May 3, 2004) (transcript available at http://brownvboard.org/video/blackwhitebrown) (statement of Roger Wilkins).
} 